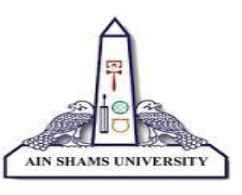

Ain Shams University

Faculty of Education

Department of Curricula (TEFL)

\title{
A Program Based on the Inquiry Approach to Develop the EFL Majors' Language Performance at Al-Azhar University in Palestine
}

\author{
A Dissertation \\ Submitted in a Partial Fulfillment of the Requirements for \\ the Ph.D. Degree in Education \\ Curricula (TEFL) \\ Prepared by \\ Reem S. AbuRezeq \\ Lecturer of Curricula (TEFL) \\ Al-Azhar University- Palestine \\ Supervised by \\ Dr. Asmaa Gheith \\ Professor of Curricula \\ (TEFL) \\ Ain shams University \\ Dr. Mohamed Hamdan \\ Assistant Professor of Curricula \\ (TEFL) \\ Gaza University
}




\begin{abstract}
The current research aims at developing EFL Majors' language performance in general, and writing in particular at Al- Azhar University in Palestine in the light of the inquiry approach. To achieve this, a group of $3^{\text {rd }}$ year, English department students $(n=115)$ participated in the study. The researcher designed a writing performance test of 6 components; identifying main ideas, posing questions, paraphrasing, narrating, problemsolving and argumentation. The pretest revealed that most of the participants' writing performance was not up to the required level. Therefore, the researcher engaged them in a program based on the inquiry approach which took place in the academic year 2017-2018. This study employed the one group experimental design along with mixed research approach incorporating quantitative and qualitative analyses. After treatment, the post-test showed that there was a significant development in students' writing performance. Furthermore, the participants showed positive reflections towards the program. The study findings indicated the effect of the program in developing the participant's writing performance. In light of these findings, the researcher stated some pedagogical implications, limitations and recommendations.
\end{abstract}

Keywords: inquiry approach, language performance, writing performance 
مستخلص البحث:

يهدف البحث الحالي إلى تطوير الأداء اللغوي لدي طلاب اللغة الإنجليزية لا سيما في

الاداء الكتابي في جامعة الأزهر بفلسطين في ضو هنهج الاستقصاء.وتماثشيا مع اهداف البرنامج، تم تصميم الاختبار القبلي والبعدي للأداء الكتابي. ولتحقيق هذا الهدف استخدم الباحث عينة من

صممت الباحثة اختبار لقياس أداء الكتابة مكونا من ستة عناصر وهي تحديد الأفكار الرئيسية و طرح الأسئلة و إعادة الصياغة و السرد وأسلوب حل المشكلات والجدال. أظهر الاختبار القبلي أن معظم المشاركين لم يكونوا جيدين بما فيه الكفاية لتحديد الأفكار الرئيسية وطرح الأسئلة وإعادة الصياغة والحوار وحل المشكلة والجدال. لذلك، قامت الباحثة بدمج المشاركين في برنامج يستند إلى منهج الاستقصاء الذي تم تتفيذه في العام الدراسي 2017-2018. استخدمت هذه الدراسة التصميم التجريبي لمجموعة واحدة إلى جانب التحليل الكمي والنوعي. بعد تطبيق البرنامج ، أظهر الاختبار البعدي أنه كان هناك تغيير كبير في أداء الكتابة. علاوة على ذلك ، تم وصف اراء المشاركين الايجابية نحو البرنامج. أشارت نتائج الدراسة إلى فعالية البرنامج في تطوير الأداء اللغوي مع التركيز على الأداء الكتابي • في ضوء هذه النتائج ، ذكر الباحث الآثار التربوية والتوصيات وعرض المشكلات التي واجهته اثناء تطبيق البحث الحالي. 


\section{Introduction}

It has become clear that education reform in the $21^{\text {st }}$ century should focus on students' performance in all aspects of learning. This elicits the students' self-direction and independence. The need to teach students to perform and act well in foreign language is essential for successful learning.

The concept of performance grounded in Hymes (1972), quoted by Newby (2011) refers to the actual use of language. It includes students' responses either in an oral or a written form (Abbott \& Wren, 2016). The importance of integration of oral and writing areas is emphasized by Rivard and Straw (2000) who indicated that many studies in the fields of oral and written performance get benefits of both of them. The role of language performance is evident in creating a real-life situation for learner to practice language performance. According to the study of both Nation and Newton (2009), learners should write and speak about issues that they are familiar with and use communication strategies so as to convey messages to someone else.

Language performance integrates both oral and written areas. However, it might be beneficial to deal with the written aspects in order to make it easier for assessment. At the same time the target functions imply the integration of both oral and written activities such as arguments, questioning, group dynamic activities through the students' preparation of providing evidences, comparing cases, discovering contradictions, criticizing, and asking questions (Harpaz, 2005).

It is worth mentioning that writing comes out naturally with oral activities. Also, it could be helpful for some inspiration after oral 
activities. However, oral performance may follow writing which makes the discussion more evidence-based. This finding provides empirical evidence verifying several scholars' hypothesis about the value of the use of talk and writing in sequence (Berland \& McNeill, 2010; Erduran \& Jimenez \&, 2008).

The significance of using writing performance to assist students in the construction of knowledge is emphasized by Torrance, Galbraith and Waes (2007) who stated that writing is not just a speech written down. But it also includes understanding the processes involved in producing and evaluating thoughts rather than the processes involved in translating thoughts into the language.

Due to the importance of writing performance, students should be given the opportunities that would develop their writing performance. Therefore, it is important to shed light on some strategies and techniques that may enhance the students' writing performance. The following areas may be included in the inquiry approach:

- Developing student-centered approach (Renau, 2016).

- Improving critical thinking (Duran \& Dokme, 2016).

- Increasing higher order thinking (Lin \& Kharrufa, 2014).

- Presenting authentic communication (Hart \& Lee, 2003).

- Offering hands-on activities (Hart \& Lee, 2003).

- Generating students' questions (Hart \& Lee, 2003).

- Giving priority to evidence, explanation, and justification (NRC, 2000).

- Engaging students in analyzing concrete data for writing tasks (Graham \& Perin, 2007). 
- Providing activities that guide learners to generate meaningful questions (Ismael, 2006).

In contrast to traditional pedagogy, inquiry-based engages students in learning activities which are based on constructivism theory. The focus shifted from teacher-led to student-centered learning (Ozmon $\&$ Craver, 2008). In the opening phases of the inquiry approach, educators may support learners' success by activating or building their background knowledge. So, the teacher's role is to present puzzling events, question, or problem whereas the students formulate hypotheses, collect data, test the hypotheses, draw conclusions, and reflect on the original problem (Banchi \& Bell, 2008; Lasley et al. 2002; Woolfolk, 2013).

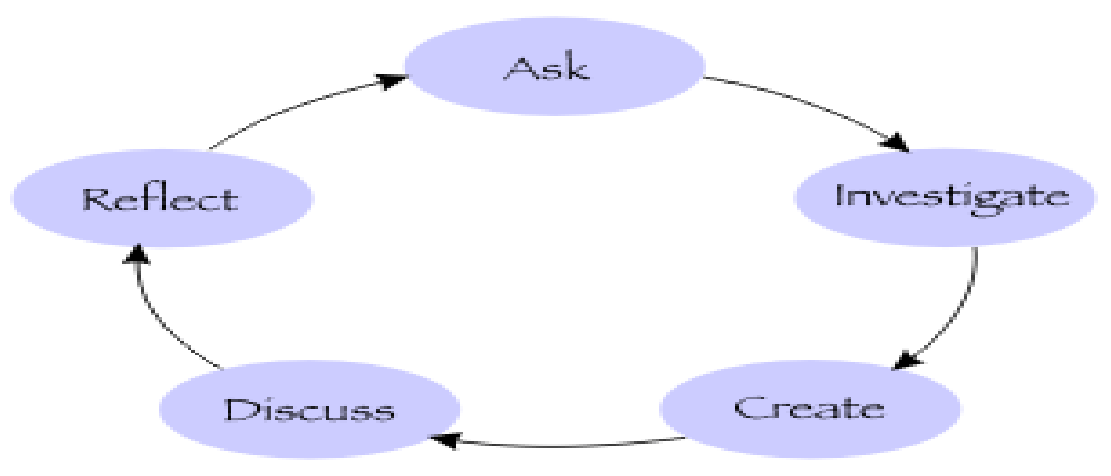

Figure 1. Inquiry Based Learning Cycle (Dewey, 1910).

As far as is shown above by inquiry cycle diagram, it is noticed that it comes up with five stages where asking comes at the first in which students try to prepare their tasks and formulate meaningful questions about a problem or topic they have to discuss. Next, investigating, in which students get together in sub-groups and narrow the topic, is called information-gathering step. Then comes creating; in which students are to make connections. After that comes discussing, in which such new 
discoveries are shared with other members of their sub-group. At this phase, students meet the purpose of their research and start comparing notes and discussing conclusions with members. The final stage is reflecting, in which students get together once again in order to analyze once more the whole research process and the conclusions made, including the information received by online collaborators. They also prepare for the final written reports and oral group presentations. It is indicated that inquiry cycle moves through different phases; asking, investigating, creating, discussion and reflecting (Dewey, 1910 \& Pedaste et al., 2015).

The integration of inquiry approach into teaching requires certain features, for example, inquiry approach involves generating questions, designing experiments, gathering evidence, making claims, and justifying claims. It also includes learning by discovery, problem-solving, learning projects, generating questions, designing experiments, gathering evidence, making claims, and justifying claims. Each of these approaches stresses different parts of what is considered "inquiry". The inquiry also varies along a continuum of teacher-directed to student- directed where students should have an opportunity to understand the whole world around deeply through collecting data, solving problems and thinking logically and critically. Thus, the students of the inquiry-based classrooms reported being more interested and satisfied regarding the subjects they studied (Kahle et al. 2000; NRC, 2000; Westwood, 2000). Hence, it is beneficial to make use of such features in the present study. 


\section{Context of the Problem}

Writing performance is important for students. Most EFL majors in Palestine lack a clear understanding of writing performance. This may be due to the lack of applying strategies and techniques in an authentic context focusing on this type of writing performance. Within the previous frame, the following studies show the weakness of students' writing performance and the reasons behind such situation:

The interference of the mother tongue might be one of the reasons as mentioned by Nik et al. (2010) and Derakhshan \& Karimi (2015) who investigated the relation between first language and second language acquisition. They confirmed that the problem of students' writing performance is related to their first language. The researchers found out that those students who do not read or write well in their first language need to work harder in their second language.

Another reason for inefficient writing performance is the deficiency of writing argumentative texts which is evidenced by Ibrahim (2015) who stated that most of $2^{\text {nd }}$ year English majors lacked the ability to write a comprehensive, well-organized and logically supported argumentative text which negatively affected their writing performance. The researcher recommended that more attention should be paid to investigating and implementing approaches that may enhance students' writing performance.

The difficulty of writing is also extended to extracting ideas which is concluded by Chin (2016); the difficulty of writing is resulted from reformulating and integrating new ideas. The researcher, therefore, asserted the need for more training courses on how to rearrange and 
reorganize ideas. In general, writing is a complex task which requires a higher level of thinking. Therefore, prospective teachers should waste no effort to have students achieve that well (Alfaki, 2015; Nik et al. 2010; Schoonen et al., 2003).

In addition, some teachers are not clearly aware of the current writing strategies. Therefore, much of teaching writing still focuses on a traditional approach that concentrates on the language structure knowledge and mechanical writing improvement too; as a result of imitation of input in the form of texts provided by the instructors (Kakandee, 2017).

On the other hand, the following studies adopt inquiry approach and show the effectiveness of adopting the inquiry approach in comparison to ordinary teaching methods. For example, Bularafa \& Preece (2015) investigated the effectiveness of community of inquiry method in preparing students to develop listening and speaking skills in a sample about 100 participants of junior secondary school. The study revealed that community of inquiry approach is a good method of teaching speaking skills and teachers should be encouraged to master and employ the framework for developing English language.

A large study conducted by Applebee et al. (2003) examined the relationship between student performance and discussion-based inquiry approaches and its affects on the development of English students in order to determine whether the teacher primarily focused on fostering student inquiry into literary themes or whether they emphasized simple recall of details of plot and character. The results revealed that discussion-based 
inquiry approaches are significantly related to improving student performance.

Implementing the inquiry approach into the cooperative atmosphere is essential as seen in AbuelSaman (2008) and Asiala (2011) which showed the great effect of applying inquiry-based cooperative learning in comparison with traditional strategy. This comparison reveals that the students who were exposed to both strategies of inquiry and cooperative learning were better than those who were exposed to traditional strategies.

Other studies have been conducted to improve the educational experience in light of inquiry approach (Castkovaa \& Kropaca, 2014; Darayesh, 2003; Mc Gregor, 2001). They adopted a variety of activities based on the inquiry approach, discussion, questioning, mind mapping and brainstorming in order to develop self-concept, cultural, linguistic and creative solutions respectively. Hence, it is beneficial to make use of such activities in the present study.

Due to the previous reasons, the researcher decided to design inquiry approach program to present activities in order to develop the target students' writing performance.

The researcher believes that there is an urgent need to develop writing performance for students at the English Department, Faculty of Education at Al-Azhar University.

Based on the researcher's experience in teaching at Al-Azhar University, she noticed that the students' writing performance is almost poor. This may be due to the traditional teaching and learning techniques 
used in teaching writing. This elicited further accurate investigation to reveal the deficits of their writing performance through the pilot study.

\section{The pilot Study}

The researcher conducted a pilot study on 50 students randomly selected to investigate their writing performance. The results proved that many of these students lacked essential writing performance; their mean score was $22 \%$. The researcher asked some questions that can reveal their actual performance features (Appendix A). The pilot study showed a clear weakness of students' writing performance in terms of finding main ideas, paraphrasing, posing questions, narration, problem-solving and argumentation.

The following results were arrived at;

- Students could not almost identify ideas.

- Even their paraphrasing texts could not show deep understanding.

- Their writing was a mere direct answer of the suggested questions.

- They could not build or narrate a story because they lack vocabulary, and had no idea about joining words, events, characters, plot...etc., i.e the storyboard.

- They were not used to solving problems if they had any because they do not know the problem solving techniques.

- They could not engage in argumentative writing, as it needs presenting supporting and opposing ideas. 


\section{Statement of the Problem}

Based on the previously mentioned analytical points, there is a necessity to conduct a program based on the inquiry approach to develop the EFL majors' language performance at Al- Azhar University in Palestine.

The present study attempts to answer the following main question:

What is the effect of a program based on the inquiry approach on developing the EFL majors' writing performance at Al-Azhar University in Palestine?

In an attempt to answer the above question, the following subquestions were also raised:

1- What is the existing level of the EFL majors' writing performance?

2- What are the activities and writing prompts based on the inquiry approach to develop the target students' writing performance?

3- What are the components of a program based on the inquiry approach?

4- What is the effect of the proposed program on the target students' writing performance?

\section{Design of the Study}

The present research adopts one group experimental study design. The intact group members were tested before conducting the program. During the program, the group members were taught using some activities based on the inquiry approach. At the end of the experiment, the group members were post-tested. 


\section{Delimitations}

The current research is delimited to the following:

- Participants are group of $3^{\text {rd }}$ level female English majors $(n=115)$ at AlAzhar university.

- The study was carried out over a period of 3 months, 32 sessions, 32 hours in the academic year 2017-2018.

- Writing performance was selected for flexibility of assessment.

- Some face to face and online activities based on the inquiry approach relevant to the targeted writing performance components for the study participants.

\section{Significance of the Study}

This study is expected to be of importance for:

- Students: they can apply various strategies and activities by which they can enhance writing performance towards different issues, thinking deeply to ask deep questions, paraphrasing effectively to give deep meaning, narrating smoothly to provide experience towards different topics, thinking positively to suggest solutions of problems, and arguing with people to accept and reject others' opinions in a logical way.

- Teachers: as they will be provided with a variety of suggestions and activities that can effectively enhance their EFL students' writing performance.

- Policy makers: they make use of inquiry approach in attempting to develop or renew the curricula and teaching materials, in order to enhance learners' writing performance. 


\section{Hypotheses}

The study hypotheses were as follows:

1- There would be a statistically significant difference between the mean scores of the pre-test and the post-test of the study group in terms of developing main ideas in favor of the post-test.

2- There would be a statistically significant difference between the mean scores of the pre-test and the post-test of the study group in terms of developing posing questions in favor of the post-test.

3- There would be a statistically significant difference between the mean scores of the pre-test and the post-test of the study group in terms of developing paraphrasing in favor of the post-test.

4- There would be a statistically significant difference between the mean scores of the pre-test and the post-test of the study group in terms of developing narration in favor of the post-test.

5- There would be a statistically significant difference between the mean scores of the pre-test and the post-test of the study group in terms of developing solving a problem in favor of the post-test.

6- There would be a statistically significant difference between the mean scores of the pre-test and the post-test of the study group in terms of developing argumentation in favor of the post-test.

\section{Definitions of Terms}

\section{Writing Performance}

Using the term of performance in writing classes provides a clear description of language use in expressing, explaining, justifying, critizing 
and asking within academic contexts (Harpaz, 2013; Harris \& Jones, 2016 \& Nik et al., 2010).

In the present study, writing performance is an integration process through which students identify ideas, paraphrase to show deep understanding, pose deep questions, narrate stories, find alternatives for problem solving and present supporting and opposing ideas of argumentation.

\section{Inquiry approach}

The inquiry approach focuses on investigation, exploration, searching, questing, researching, pursuing, and studying. It is not only developing questions but also examining how these questions affect the world around them. Therefore, it is escalated by social, historical and cultural interaction where learners are more involved with a community. It is also concerned with the historical world (Melorose et al., 2015; Hebrank, 2000 \& Kuklthau et al., 2007).

In the present study, the inquiry approach is the framework that provides the students with rich opportunities to perform writing in an authentic context, so that they can identify ideas, paraphrase, raise questions, narrate, solve problems and argue.

\section{Conclusions}

The purpose of this study was to investigate the effectiveness of a program based on the inquiry approach for enhancing the English department students' writing performance. Based on the previously 
discussed findings and quantitative and qualitative analyses conducted in chapter 4 , the following conclusions were gleaned:

- Implementing the inquiry approach proved to be effective in developing English language majors' writing performance.

- The qualitative analysis of students' writing performance indicated that they became more aware of what is meant by writing performance, had the chance to practice writing easily without stress, received constructive feedback on what they wrote and finally developed their vocabulary and oral performance along with their writing performance.

- The participants were provided with successful language learning experiences which motivated their participation and improved their writing performance.

- The participants were satisfied with the inquiry approach as they expressed in their opinions in chapter four.

- The program provided hands-on experiences that included different techniques of the inquiry approach.

\section{Pedagogical Implications}

The findings of this study revealed that there are some pedagogical implications that may provide positive effects when adopting the inquiry approach in teaching writing performance:

- The program shed light on the importance of the inquiry approach as an authentic context and rich environment for learning. 
- The face to face and online activities of the inquiry approach served to deepen the participants' understanding.

- The inquiry approach was flexible enough to be adapted to meet specific lesson objectives and participants' needs.

- The program provided a rich knowledge through which instructors could facilitate these types of learning processes for all of their learners.

- The program changed the role of the teacher- led to studentcentered learning.

- The program provided different tasks and techniques to learn language performance in general and writing performance specifically.

- The participants reflected their deep appreciation towards the effect of the inquiry program, in comparison to the traditional applied techniques.

\section{Difficulties Encountered throughout Treatment}

There are some limitations encountered throughout the treatment:

- It was found that most participants were afraid of writing and using graphics or storyboard. Therefore, the researcher provided different techniques and tasks that facilitated the process. This will likely to be effective in developing their ability to write topics with little mistakes.

- It was less difficult for most participants to debate because they did not have enough knowledge. As a result, the researcher suggested different topics related to their interest. With this 
variety of topics, they will expand their knowledge so that they could discuss any topic easily.

- In the beginning of the classes, the participants were a bit careless. However, as they benefited more from the course, they started to attend class regularly. Therefore, instructors should motivate their students in order to engage them into learning.

- It is not sufficient to teach some students to show deep understanding when they paraphrase or pose questions. This can be attributed to their lack of deep thinking. Therefore, the researcher provided the inquiry approach activities to explore the hidden meanings.

- As for argumentation and narration, most participants were not able to engage in this activity. This can be attributed to their lack of vocabulary and shyness to deliver correct phrases. Therefore, the researcher provided students with different techniques of storyboard and prewriting techniques to organize their thoughts and enhance their writing performance.

- The classes were not really adequate for learning through the inquiry sessions. There were some obstacles which included; a regular cut of electricity and poor use of computer lab. However, the researcher tried to use the microteaching labs and the library to create a rich environment for the participants.

- It was a challenge for the researcher to meet all the participants' needs and wishes due to their big number. Therefore, it is necessary to use different techniques based on effective approaches to enhance their writing performance. 


\section{Recommendations}

In the light of the review of literature, theoretical framework and the study results, the researcher recommends:

- Incorporating the inquiry approach in all language classroom.

- Choosing topics that appeal to students' interest and background knowledge.

- Using pre-writing graphic organizers and storyboard for developing students' writing performance.

- Presenting materials based on internet search to the students to simulate their inquiry abilities.

- Developing teachers' pedagogical knowledge of the inquiry approach and the attached strategies.

- Enhancing self-expression ability as a prerequisite for language learners.

- Participating in oral and written activities as highly appreciated practices of learners.

\section{Suggestions for Further Research}

Researchers may further explore the effectiveness of using the inquiry approach in developing writing performance. The following are some examples of the studies that may be attempted:

- Conducting ethnographic case studies using the inquiry approach to develop writing performance.

- Investigating the effect of using the inquiry approach on teachers' professional development. 
- Exploring the students' perceptions of using the inquiry approach in learning the English language in general and in improving their writing performance in particular.

- Designing a training program to encourage teachers to use the inquiry approach.

- Using the task based inquiry approach to develop students' writing performance.

- Using storyboard based research in an action research study. 


\section{References}

Abbott, A., \& Wren, D. (2016). Using Performance Task Data to Improve Instruction. Educational Strategies, 89(1), 38-45.

AbuelSaman, N. (2008). The effect of using inquiry-based, cooperative learning and the ordinary strategy on English reading comprehension of university students in the kingdom of Saudi Arabia (Master dissertation). Univeristy of Saudi Arabia, Saudi Arabia.

Asila , J. (2011). Comparison of the effects of inquiry-based cooperative learning and demonstrations in science education (Master dissertation). Michigan Technological University, United States.

Alfaki, I. M. (2015). University Students' English Writing Problems: Diagnosis and Remedy. International Journal of English Language Teaching, 3(3), 40-52.

Applebee, N., Langer, J., Nystrand, M., \& Gamoran, A. (2003). Discussion-Based Approaches to Developing Understanding: Classroom Instruction and Student Performance in Middle and High School English. American Educational Research JournaL, 40, 685-730.

Banchi, H., \& Bell, R. (2008). The many levels of inquiry. Science and Children, 46 (2), 26-29.

Berland, L., \& McNeill, K. (2010). A learning progression for scientific argumentation: Understanding student work and designing supportive instructional contexts. Science Education, 94(5), 765-793.

Chin, J. S. (2016). Investigating the summary writing performance of university students in Taiwan. 20th conference of English teaching and learning in the R.O.C. The language training and testing center. 
Darayseh, A. (2003). The Effect Of a Proposed Program Based On Semantic Mapping and Brainstorming Strategies on Developing the English Writing Ability and Attitudes, First Scientific Secondary Students. College of Educational studies, Amman Arab University for Graduate studies, Amman.

Derakhshan, A., \& Karimi, E. (2015). The Interference of First Language and Second Language Acquisition. Theory and Practice in Language Studies, 5(10), 21122117.

Dewey, J. (1910). Science as Subject Matter and Method. Science, 28, 121-127.

Duran, M., \& Dokme, I. (2015). The effect of the inquiry- based learning appraoch on student's critical- thinking skills. Journal of math, science and technology education, 12(1), 2887-2908.

Erduran , S., \& Jimenez-Aleixandre, M. P. (2007). Argumentation in Science Education. Perspectives from classroom Based research. United Kingdom : Springe.

Harpaz, Y. (2005). Teaching and Learning in a Community of Thinking. Journal of Supervision and Curriculum, 20( 2), 136-157

Harris , A., \& Jones, S. H. (2016). Writing for Performance. Teaching Writing Monash University, Australia: Sense Publishers.

Hart, J. E., \& Lee, O. (2003). Teacher professional development to improve the science and literacy achievement of English language learners. Bilingual Research Journal, 27(3), 475-501.

Hebrank, M. (2000). Why inquiry -based teaching and learning in the middles school science classroom? Retrieved 2 3, 2017, from www.biology.duke.edu/cibl/inquiry/why_inquiry_in_ms.htm 
Ibrahim, D. (2015). The Effect of a Collaborative Learning-based Prgram on Developing English Majors' Argumentation Writing (Doctoral dissertation). Ain Shams, Egypt.

Ismail , N. . (2006). Inquiry Based Learning: A new Approach To Classroom Learning. English Language Journal, 1(2), 13-24.

Kahle , J. B., Meece , J., \& Scantlebu, K. (2000). Urban African-American middle school science students: Does standards-based teaching make a difference? Journal of Research in Science Teaching, 37(9), 1019-1041.

Kakandee, M. (2017). Law Students' Essay Writing Performance and their Writing Difficulties. European Journal of Language and Literature Studies, 9(1).

Kropac, J., \& Castkova, P. (2014). Pupil's Self-Concept in Inquiry-based Technical Education. Procedia - Social and Behavioral Sciences., 186, 776-784.

Kuhlthau, C. C., Maniotes , L. K., \& Caspari, A. K. (2007). Guided inquiry: Learning in the 21st century. London, CT: Libraries Unlimited.

Ismail , N. (2006). Inquiry Based Learning: A new Approach To Classroom Learning. English Language Journal, 1(2), 13-24.

Lasley, T., Matczynski, T., \& Rowley, J. (2002). Instructional models: strategies for teaching in a diverse society ( $2^{\text {nd }}$ ed.). Belmont, CA: Wadsworth.

Lin, M., Preston, A., \& Kharrufa, A. (2014). Collaborative enquiry through the tabletop for second/foreign language learners. In S. Jager, L. Bradley, E. J. Meima, \& S. Thouesny (Eds), CALL Design: Principles and Practice; Proceedings of the 2014 EUROCALL Conference, Groningen, The Netherlands. (pp. 202-208).

Mc Gregor, G. (2001). Creative Thinking instruction for a college study skills program: A Case study (Doctoral dissertation). Baylar University, United states. 
Mohamed , A. A. (2010). The Effect of the Problem Solving Approach on Developing Prep Stages Students' EFL Writing Skills (Master dissertation). Ain Shams University, Egypt.

Melorose, J., Melorose, J., Perroy, R., \& Careas, S. . (2015). An Exploration of Inquiry in the English Classroom. Statewide Agricultural Land Use Baseline Journal, $1,163-172$.

Nation, I., \& Newton, J. (2009). Teaching ESL/EFL Listening and speaking. New York: Routledge.

National Research Council. (2000). Inquiry and the National Science Education Standards. Washington, D.C: National Academy Press.

Newby, D. (2011). Competence and performance in learning and teaching: theories and practices. University of Graz, Austria

Nik, Y., Sani, B., Chic, M., Jusoff, K., \& Hasbollah, H. (2010). The writing performance of undergraduates in the University of Technology Mara, Terengganu, Malaysia. Journal of Languages and Culture, 1(1), 8-14.

Ozmon, H. A., \& Craver, S. M. (2008). Philosophical foundations of education. Upper Saddle River, NJ: Pearson/Merrill Prentice-Hall.

Torrance, M. , Galbraith, D. \& Waes , L. (2007). Writing and cognition: Research and applications. Amsterdam: Elsevier.

Pedaste , M., Maeots , M., Jong, T. d., Riesen, S. A., Kamp, E. T., Manoli, C. C., Tsourlidaki, E. (2015). Phases of inquiry-based learning: Definitions and the Inquiry Approch. Educational Research Review(14), 47-61.

Preece, A. D., \& Bularafa, M. W. (2015). Community of Inquiry Method and Language Skills Acquisition: Empirical Evidence. Journal of Education and Practice, $6(27)$. 
Graham , S., \& Perin, D. (2007). Effective Strategies To Improve Of Adolescents In Middle And High Schools. A report to Carnegie Corporation of New York. Washington, DC: Alliance for Excellent Education.

Renau , M. L. (2016). A Review of the Traditional and Current Language Teaching Methods. International Journal of Innovation and Research in Educational Sciences. 3(2). 2349-5219

Schoonen , R., Gelderen , A. v., Glopper, K. d., Hulstijn , J., Simis, A., Snellings, P. , \& Stevenson, M. (2003). First Language and Second Language Writing: the Role of Linguistic Knowledge, Speed of Processing, and Metacognitive Knowledge. Language Learning, A Journal of Research in Language Studies 53(1), 165-202.

Westwood, P. (2008). What Teachers Need to Know About Teaching Methods?. Ligare, Australia: Camberwell. 